\title{
Spatial distribution and sample size to estimate Lycosa erythrognatha (Araneae: Lycosidae) population density overwintering
}

\author{
E. Engel ${ }^{a *}$ (D), M. P. B. Pasini ${ }^{b}$ (D) and N. A. Kist ${ }^{b}$ (D) \\ a Universidade de São Paulo, Escola Superior de Agricultura “Luiz de Queiroz", Departamento de Entomologia e \\ Acarologia, Piracicaba, SP, Brasil.

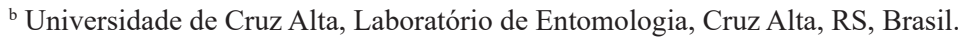 \\ *e-mail: agron.engel@gmail.com
}

Received: December 28, 2019 - Accepted: April 30, 2020 - Distributed: November 30, 2021

(With 6 figures)

\begin{abstract}
Lycosa erythrognatha Lucas, 1833 (Araneae: Lycosidae) is a predatory arthropod with potential for conservation biological control. In addition to being considered a bioindicator of environmental quality, this arthropod provides an important service for agriculture by reducing insect-pest populations. In this work we seek to understand how the plants Andropogon bicornis L., Saccharum angustifolium Nees and Eustachys retusa Lag (Poales: Poaceae) and their different clump sizes affect the population density, spatial distribution and determination of the minimum number of samples to estimate its population density during the winter. Among the evaluated host plants, S. angustifolium and A. bicornis presented higher population density than E. retusa, but we observed that the clump diameter significantly influences the population density and the minimum number of samples. We observed a gregarious behavior in plants of $A$. bicornis and E. retusa. For $S$. angustifolium, a uniform distribution was observed.
\end{abstract}

Keywords: predatory arthropods, hibernation sites, biological control, monitoring.

\section{Distribuição espacial e tamanho de amostra para estimar a densidade populacional de Lycosa erythrognatha (Araneae: Lycosidae) durante o inverno}

\begin{abstract}
Resumo
Lycosa erythrognatha Lucas, 1833 (Araneae: Lycosidae) é um artrópode predador com potencial para controle biológico de conservação. Além de ser considerado um bioindicador da qualidade ambiental, esse artrópode fornece um importante serviço para a agricultura, reduzindo as populações de insetos-praga. Neste trabalho buscamos entender como as plantas Andropogon bicornis L., Saccharum angustifolium Nees e Eustachys retusa Lag (Poales: Poaceae) e seus diferentes tamanhos de touceira afetam a densidade populacional, distribuição espacial e a determinação do número mínimo de amostras para estimar sua densidade populacional durante o inverno. Entre as plantas hospedeiras avaliadas, S. angustifolium e A. bicornis apresentaram maior densidade populacional que E. retusa, observamos que o diâmetro da touceira influencia significativamente a densidade populacional e o número mínimo de amostras. Observamos um comportamento gregário nas plantas de A. bicornis e E. retusa. Para S. angustifolium, uma distribuição uniforme foi observada.
\end{abstract}

Palavras-chave: artrópodes predadores, locais de hibernação, controle biológico, monitoramento.

\section{Introduction}

Spiders are studied in many environments. However, studies in different biomes involving sampling techniques, fauna composition and diversity under different impacts, management and periods are still needed (McDonald, 2007; Haddad et al., 2015; Horváth et al., 2009). Those arthropods are known for their importance to the environment besides being considered bio-indicators of forests, degraded areas (Podgaiski et al., 2013) and agroecosystems (Rodrigues et al., 2009; Lee et al., 2014; Baba and Tanaka, 2016).
Of the 110 spider families recorded worldwide, only a few are found in agroecosystems: Lycosidae, Salticidae, Oxyopidae, Clubionidae, Miturgidae, Thomisidae, Theridiidae, Linyphiidae, Araneidae, Tetragnathidae and Uloboridae (Romero, 2007). Despite their importance as recuperators of degraded environments, spiders also offer an important ecological service for farming in general; their role as a predator of potential harmful organisms, especially insects, occurs in important crops such as soybean (Glycine max L. Merril) and corn (Zea mays L.) (Bueno et al., 2012; Da 
Silva et al., 2014). Lycosidae spiders hunt through ambush, that is, they do not build webs. They are found in the soil acting as biocontrol agents throughout the development of crops (Bond et al., 2014).

Several studies involving the occurrence of arthropods in transects between cropped areas and native vegetation sites have been carried out, which corroborates the importance of these areas within the agroecosystem for maintaining pest insect populations overwintering (Cividanes, 2002; Bortolotto et al., 2016; Engel et al., 2018; Pasini et al., 2018). Thus, it is necessary to understand the distribution patterns and build sample plans for their potential biocontrol agents in these areas. Engel et al. (2018) observed the presence of stink bugs (Pentatomidae) in Andropogon bicornis L., Saccharum angustifolium Nees. and Eustachys retuses Lag. (Poales: Poaceae) plants overwintering. This behavior can be a motivating factor for spiders to search these aggregation sites during off-season periods, seeking shelter and abundant food. Studies indicate spiders as major natural enemies of stink bugs in agroecosystems (Morrison et al., 2017).

Plants of A. bicornis, E. retusa and S. angustifolium are randomly found in different environments with different sizes. They are considered part of the vegetation of the Brazilian southern fields, interfering in the occurrence and distribution of the individuals existing in that environment (Boldrini, 2009; Klein et al., 2013; Pasini et al., 2018; Engel et al., 2018). Among the species that seek shelter in these plants during the winter, there are important predators that help control pests. One of the most recurrent species is the spider L. erythrognatha (Engel et al., 2020).

In order to make agroecosystem management a sustainable system, the use of practices that promotes biological components and certain functions that can prevent pest attack must be considered (Sujii et al., 2010). Besides providing possible natural biological control, the use of these host plants as hibernacles may also serve as an environment for measuring the population levels of Lycosa erythrognatha (Lucas, 1833) (Araneae: Lycosidae) spiders even before the implantation of the next crop. The knowledge of theese predator's population levels can help in conservation biological control during crop development through colonization of the crop area.

Despite the number of works already done with spiders in agroecosystems, few of them seek to determine their spatial distribution and the minimum number of samples needed to make the winter population survey in areas adjacent to crops. Hence, this paper sought to answer the following questions: (i) Is the population density of L. erythrognatha variable among host plant species and between the different sizes of clumps formed by each plant species during winter? (ii) Does the spatial distribution of $L$. erythrognatha vary as a function of the host plant? (iii) Is it possible to determine a minimum number of samples for each host plant species in order to estimate the population density of L. erythrognatha during winter?

Thus, the objective of this work was to evaluate the population density, spatial distribution and the minimum number of samples necessary to estimate the population of L. erythrognatha in plants of Andropogon bicornis L., Saccharum angustifolium Nees. and Eustachys retuses Lag. (Poales: Poaceae) on the edge of a crop area overwintering.

\section{Material and Methods}

\subsection{Study area}

The study was conducted in Cruz Alta, Rio Grande do Sul state, (Figure 1), in the Experimental Area of the University of Cruz Alta - UNICRUZ (Fuso 22.244138; 6835737, UTM), during the off-season crop in soybean succession from 2014 to 2018. The climate in the study area is Cfa type according to Köppen's classification with average temperature in the coldest month below $18{ }^{\circ} \mathrm{C}$ (mesothermal) and average temperature in the hottest month

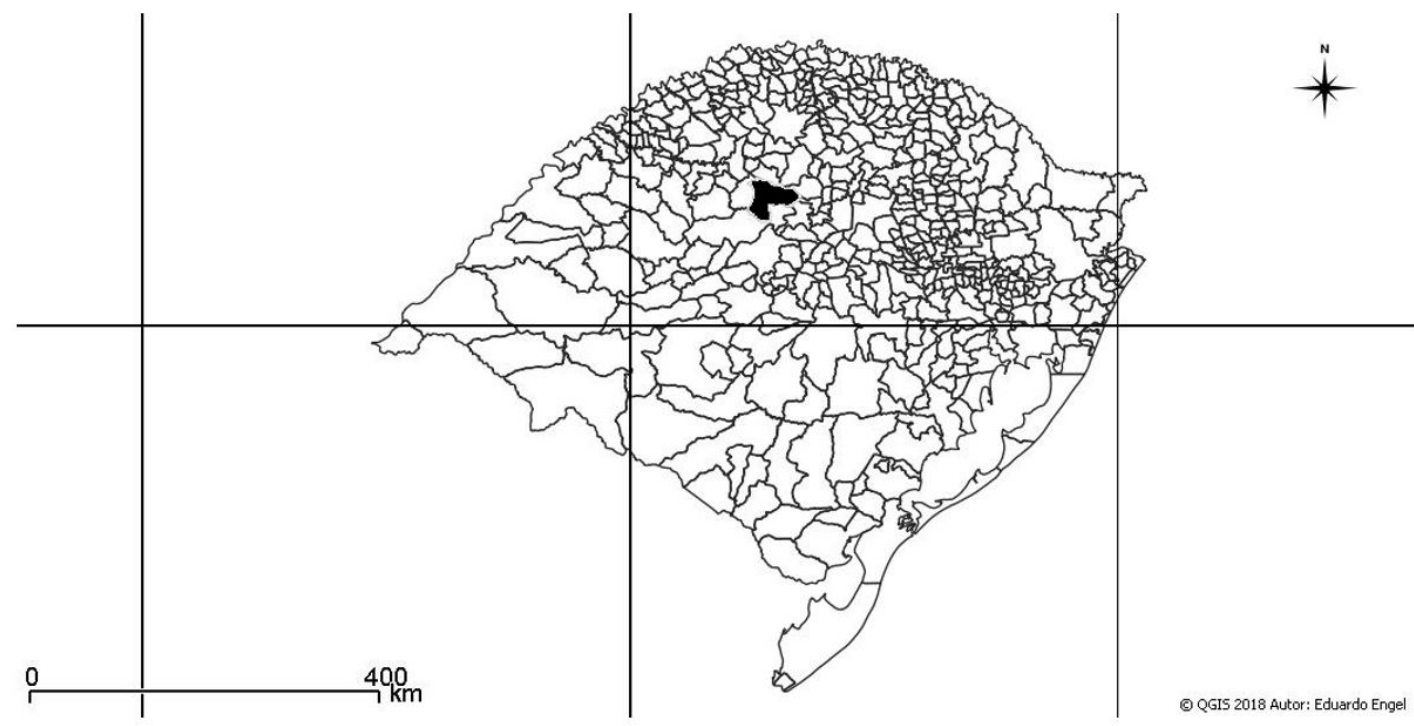

Figure 1. View of the municipality of Cruz Alta (Black polygon) in the Rio Grande do Sul state. 
above $22{ }^{\circ} \mathrm{C}$ with warm summers, infrequent frosts and a tendency for rainfall to occur in the summer months, but without a defined dry season (Kuinchtner and Buriol, 2016).

\subsection{Sampling}

Plants of the species E. retusa, A. bicornis and $S$. angustifolium located at a limit distance of 20 meters from the edge of the cultivation area were evaluated to account for the population of L. erythrognatha in the area (Figure 2). Clumps of 0-5, 5-10, 10-15, 15-20 and 20$25 \mathrm{~cm}$ in diameter were sampled for $E$. retusa and clumps with 0-10, 10-20, 20-30, 30-40 and 40-50 centimeters in diameter were sampled for A. bicornis and S. angustifolium. For each clump diameter, ten specimens were sampled per year, totaling 250 experimental units for each plant species at the end of the experiment. Occurring individuals were counted visually and each plant was considered an experimental unit. The spider identification used follows World Spider Catalog (2020) and ten indiviuals were deposited in Entomological Collection of the University of Cruz Alta.

\subsection{Statistical analysis}

Based on the number of sampled individuals, the data were organized according to the species of the host plant and clump diameter, then subjected to the normality test of Anderson-Darling and test of variance homogeneity of Bartlett. For data that did not meet the test assumptions, those were normalized through the function $\sqrt{x+0.5}$. After normalization, the data were subjected to analysis of variance and means for population density between plants compared by the Tukey test $(\mathrm{p}<0.05)$. The relationship between the clump diameter formed by each plant species and the abundance of sheltered spiders were verified through the linear regression analysis $(\mathrm{p}<0.05)$.

\subsection{Spatial distribution}

The spatial distribution of L. erythrognatha was determined in the evaluated plant species through the Taylor's coefficients $a$ and $b$, which were estimated using linear regression of the neperian logarithm of variance as a function of the neperian logarithm of the mean for the data of 250 samples divided into five years (evaluations).

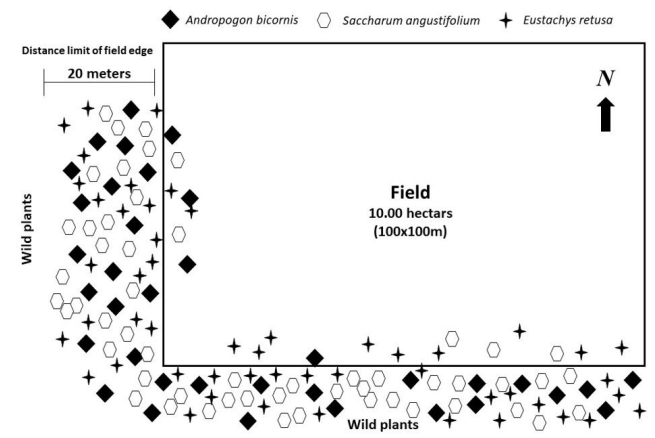

Figure 2. Sketch of the area under study and distribution of the host plants around the cropping area overwintering. Source: Authors.
Thus, the application of the neperian logarithm to both members of the equation results in the following:

$\ln s^{2}=\ln a+b \ln m$

Where $\ln a$ is the linear coeficient, $b$ is the angular coeficinet of the estimated regression equation, $s^{2}$ and $m$ are the variance and the mean, respectively.

In order to check whether b significantly differs from the unit, the t Student's test was used:

$t_{(a, N-2)}=\frac{b-1}{\sqrt{V(b)}}$

where, $b$ is Taylor's coeficinent and $V(b)$ is the estimated variance of $b$. The test was aplied at the $p<0.05$ level with N-2 degrees of freedom.

When coefficient $b$ is significantly greater than the unit, spatial distribution tends aggregate; when it is equal to or near it, there is a tendency for random distribution, and when coefficient is less than unit, spatial arrangement tends to uniformity (Taylor, 1961). Regression equations were selected based on the coefficient of determination $\left(\mathrm{R}^{2}\right)$ and the significance of $\mathrm{F}$ test.

\subsection{Sample size}

By using the 250 experimental units evaluated for each plant species $(\mathrm{n}=250)$, the sample size $(\mathrm{N})$ was estimated for the half-amplitude of the confidence intervals at 10 , $20,30,40$ and $50 \%$ (D) levels of the estimation of the mean $(\bar{x})$ of population density (spiders. plant ${ }^{-1}$ ), with a confidence level $(1-\alpha)$ of $95 \%$, using the expression proposed by Bussab and Morettin (2004):

$N=\frac{\left(\frac{t_{\alpha}^{2} * s^{2}}{2}\right)}{(D \bar{x})^{2}}$

The $t_{\alpha / 2}$ was used as the critical value of Student's $\mathrm{t}$ distribution, whose area on the right is $\alpha / 2$, that is, t such that $p\left(t>t_{\frac{\alpha}{2}}\right)=\frac{\alpha}{2}$, with (n-1) degrees of freedom, with $\alpha=0.05$ probability, $\mathrm{s}^{2}=$ estimated variance. In order to adjust the trend lines to the data obtained, a seconddegree polynomial regression analysis was performed. Then, locking $\mathrm{n}$ as 250 sample points, corresponding to the sample size used in this work, it was calculated the mean estimation error $(\bar{x})$ as a percentage for each plant using the equation $D=\left(100 * t_{\alpha / 2} * s\right) /(\sqrt{n} * \bar{x})$, where $\mathrm{s}$ is the estimate of the standard deviation. The same procedure was adopted to determine the number of samples as a function of clump diameter, only replacing the number of experimental units (50 for each diameter range).

\section{Results}

\subsection{Population density}

A total of 643 L. erythrognatha spiders distributed in the evaluated host plants were quantified in this study. A significant difference was found for $S$. angustifolium 
and $A$. bicornis among the host plants in comparison to $E$. retusa, which was the species with the smallest population density $(F=46.91, d f=2, p<0.001)$ (Figure 3$)$.

For regression analysis, a significant relationship was observed between the abundance of spiders as a function and the diameter of the clump for the three host species evaluated in the experiment (A. bicornis: $F=14.55, d f=4$, $p<0.001$; S. angustifolium: $F=25.66, d f=4, p<0.001$; E. retusa: $F=30.10, d f=4, p<0.001)$. As the clump increased, the number of spiders sheltered inside it also increased (Figure 4).

\subsection{Spatial distribution}

In order to estimate the coefficients $a$ and $b$ of Taylor's law, regressions with power trend line for the variance and the mean of the sample data were selected. Among plants, we found a better fit of the coefficient of determination $\left(R^{2}\right)$ in $A$. bicornis and $S$. angustifolium plants (0.94 and 0.87 respectively) in comparison to E. retusa

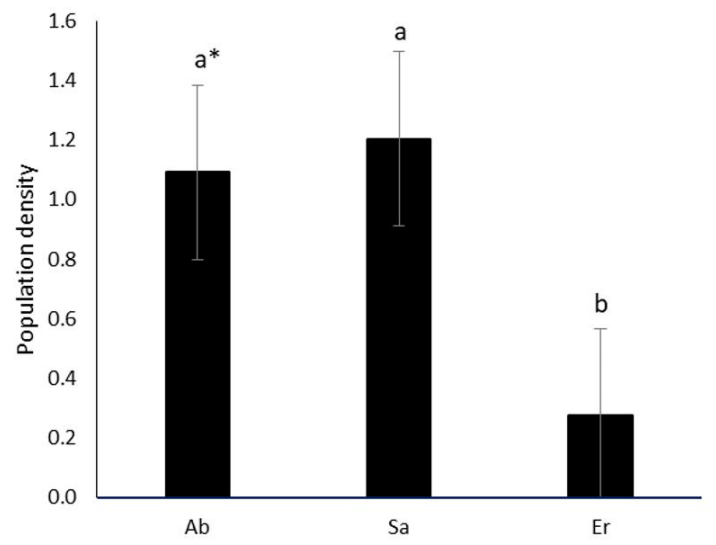

Figure 3. Population density for Lycosa erythrognatha (Lucas, 1833) (Araneae: Lycosidae) in Andropogon bicornis (Ab), Saccharum angustifolium (Sa) and Eustachys retusa $(\mathrm{Er})$ overwintering. *Equal letters are not statistically different by the test of Tukey $(p<0.05)$. Cruz Alta, Rio Grande do Sul, Brazil, 2014 - 2018.
(0.76) (Figure 5). By observing the Taylor's law parameters, we verified the possibility of using this method to analyze L. erythrognatha count data in the host plants evaluated near the cultivation area during winter, since the $\mathrm{F}$ test was significant $(p<0.05)$ (Table 1$)$

It was found for $A$. bicornis and $E$. retusa that the parameter $b$ of Taylor's law was significantly greater than 1 , indicating an aggregate distribution in these host plants. For S. angustifolium, we found that the spatial distribution showed a trend toward uniformity as the $b$ parameter was significantly less than 1 (Table 1).

\subsection{Sample size}

When the minimum number of samples to estimate the population density of L. erythrognatha for the three evaluated host plant species was verified, we noticed a high variation among host plant species when considering all evaluated clumps. However, a higher variation was also observed when considering the different sizes of clumps for the same species of the host plant.

Overall, fewer samples were found for S. angustifolium among the plants, followed by A. bicornis. In relation to $E$. retusa, we observed that a high number of samples were required, which makes the operation impracticable in practice. However, when considering the size of the clump formed in the landscape, we noticed a high reduction in the minimum number of samples for the three plant species. For ecology studies in which the levels of precision employed are generally around 90 to $95 \%$, the number of samples for $40-50$ and $20-25 \mathrm{~cm}$ diameter clumps for A. biconris, $S$. angustifolium and E. retusa was 527, 166 and 821 respectively. However, for Integrated Pest Management practices where accuracy levels are around 25 to 30\% (Southwood and Henderson, 2000; Arbab, 2014), when these diameters were taken into account, sample sizes 59, 18 and 91 were obtained for A. bicornis, $S$. angustifolium and $E$. retusa respectively, coupled with a reduction in the number of estimated samples, we also found a considerable reduction in the probability of error of these estimates.

\section{Andropogon bicornis}

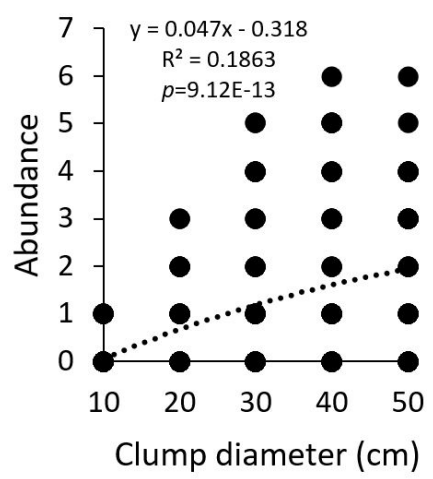

Saccharum angustifolium

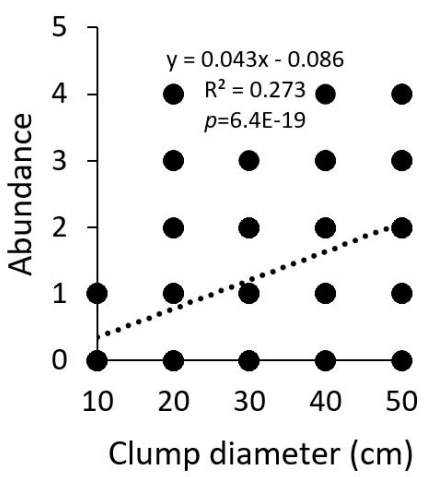

Eustachys retusa

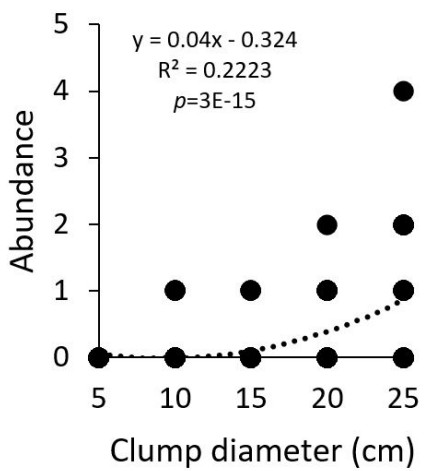

Figure 4. Population abundance of Lycosa erythrognatha (Lucas, 1833) (Araneae: Lycosidae) on Andropogon bicornis, Saccharum angustifolium and Eustachys retusa overwintering as a function of the clump diameter formed in the farming landscape. Cruz Alta, Rio Grande do Sul, Brazil, 2014 - 2018. 

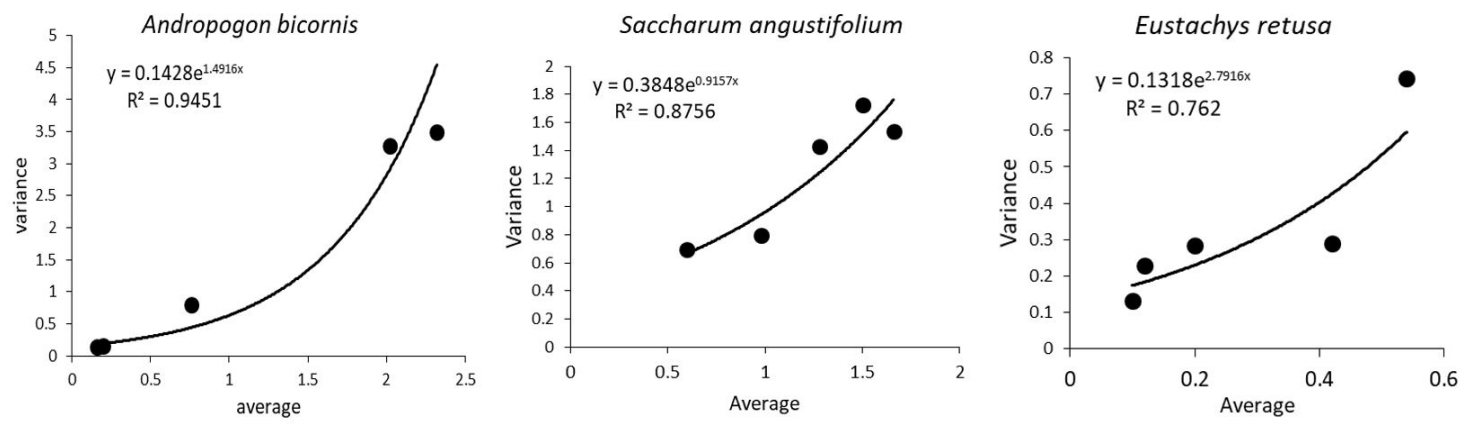

Figure 5. Relationship between variance and the mean by using the function of Taylor power for Lycosa erythrognatha (Lucas, 1833) (Araneae: Lycosidae) in Andropogon bicornis, Saccharum angustifolium and Eustachys retusa overwintering. Cruz Alta, Rio Grande do Sul, Brazil, 2014-2018.

Table 1. Estimates of Taylor's law parameters and statistics of the regression analysis for Lycosa erythrognatha (Araneae: Lycosidae) in three host plants overwintering.

\begin{tabular}{lccccccc}
\hline \multirow{2}{*}{ Host plants } & \multicolumn{2}{c}{ Parameters } & & \multicolumn{3}{c}{ Statistics } \\
\cline { 2 - 3 } & $\mathbf{a}$ & $\mathbf{b}$ & & F test & & $\mathbf{R}^{2}$ & \multicolumn{2}{c}{ T test } \\
\hline Andropogon bicornis & 0.14 & 1.50 & & $302.24^{*}$ & 0.94 & $17.38^{*}$ \\
Saccharum angustifolium & 0.38 & 0.91 & & $17.28^{*}$ & 0.87 & $4.15^{*}$ \\
Eustachys retusa & 0.13 & 2.79 & & $8.81^{*}$ & 0.76 & $2.96^{*}$ \\
\hline
\end{tabular}

*Significant at $5 \%$ probability.

\section{Discussion}

Spiders are impacted by the structural complexity of their habitat, especially with regard to the characteristic of the vegetation where they are found (Baldissera et al., 2004; McDonald, 2007; Podgaiski et al., 2013; Lee et al., 2014; Haddad et al., 2015; Horváth et al., 2015; Baba and Tanaka, 2016). We studied in this work the effect of plant species and their clump diameter on density, spatial distribution and determination of a minimum number of samples for Lycosa erythrognatha (Araneae: Lycosidae) on the edge of a crop area overwintering.

In relation to the spatial distribution of $L$. erythrognatha in the evaluated host plants, it was observed a variation in the distribution pattern due to the structural complexity of the plants, and for $A$. bicornis and E. retusa plants, there was predominance of an aggregate pattern. However, for $S$. angustifolium, a uniform distribution pattern was observed. According to Patchey and Gaston (2007), those distributions are mainly due to the structural diversity of vegetation and availability of microhabitats, as well as the interspecific competition with other spiders. Linking spatial distribution to ecological processes such as the search for host plants is paramount for understanding the behavior of beneficial arthropod populations and for building predictive models (Vinatier et al., 2011).

Even though spider communities behave as regulators of insect populations, the physical form of the environment (phytophysiognomy) (Stratton et al., 1979) is what determines the variation the most in their composition. The type of the vegetation is the primary responsible for the quality and quantity of prey available in the enviroment, besides influencing predation rates and determining microclimate conditions (De Souza, 2007; Mineo, 2009).

According to Lucio et al. (2009), the spatial arrangement of individuals in the habitat affects sampling, making it necessary to use different designs for management strategies that include the particularities of each organism to be sampled. In general, based on the model proposed by Bussab and Morettin (2004), there was a high variation between the number of samples needed to estimate L. erythrognatha population density for the different error levels established as well as between the different sizes of clumps (Figure 6).

This variation between the number of samples needed to estimate the spider population found in each plant species is mainly caused by the preference between plant species due to their structural complexity, which inflates the number of samples required for plants and clumps with a smaller probability of occupation. For Howe and Jander (2008), plants with greater structural complexity tend to harbor higher density and diversity of arthropods. Also, the size of the clump formed by each plant species in the agricultural landscape interferes with microclimate conditions, which during winter are fundamental for arthropod survival (Engel et al., 2020).

Among the species, $S$. angustifolium was the one that obtained the fewest number of plants to be sampled at the highest level of precision, followed by A. bicornis and E. retusa. S. angustifolium also presented, together with A. bicornis, a higher population density than E. retusa. The species A. bicornis and E. retusa showed a higher level of aggregation than $S$. angustifolium. All in all, our results suggest that population density, spatial distribution, and sample size estimates are influenced by host plant 

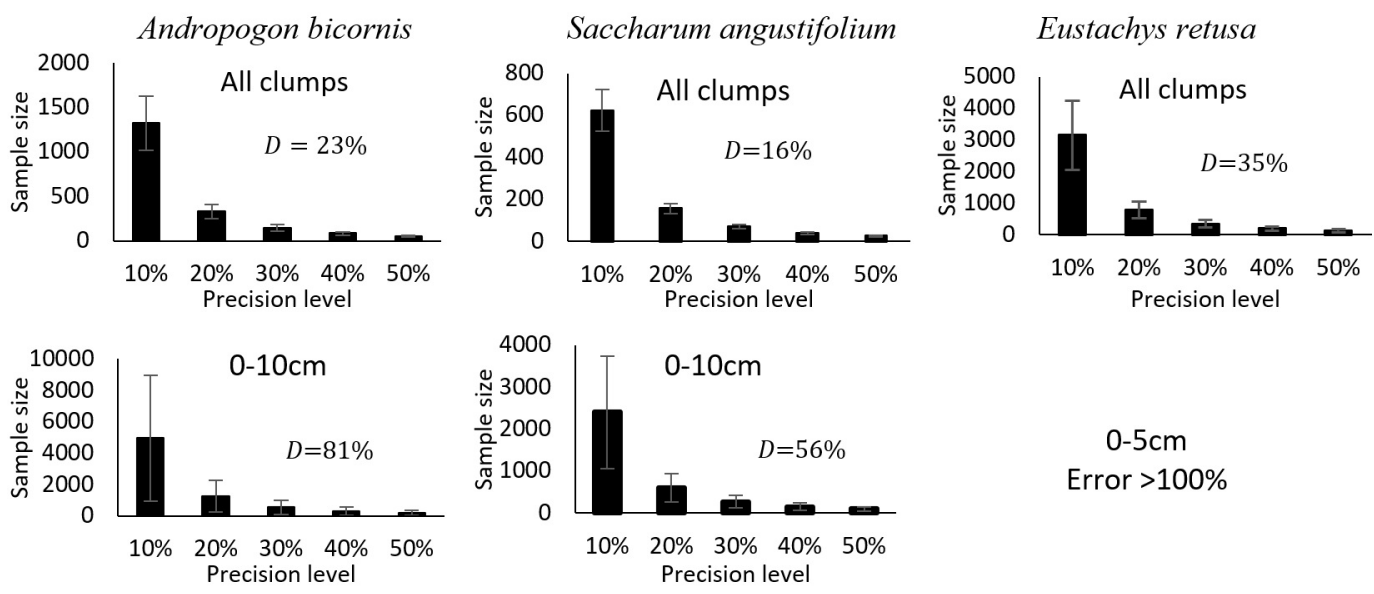
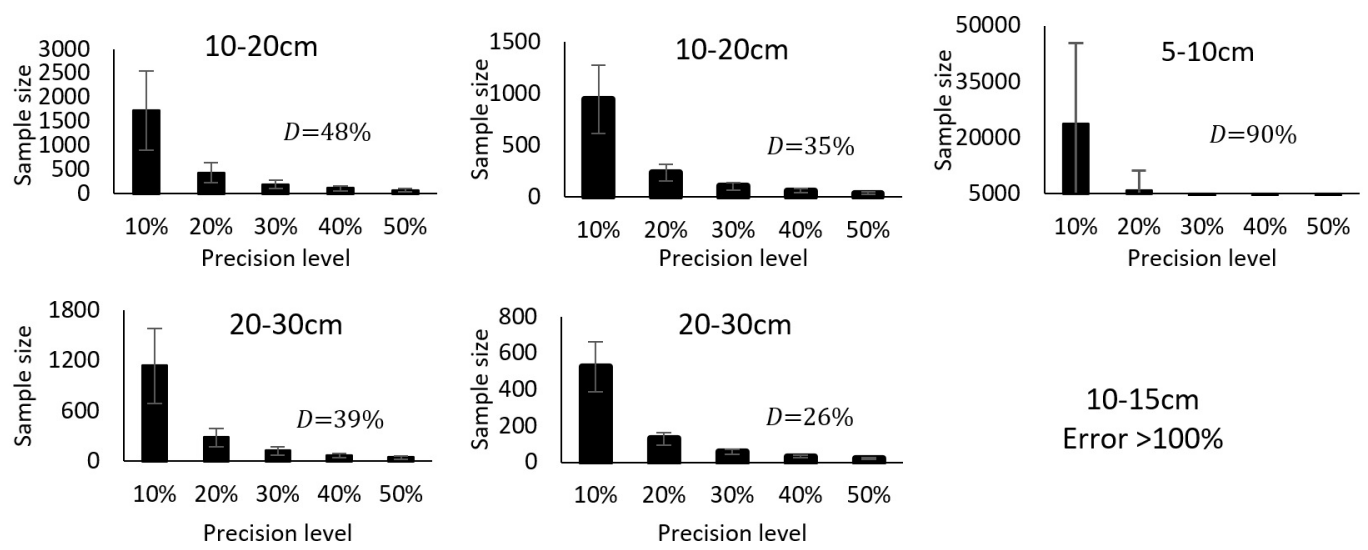

$0-5 \mathrm{~cm}$

Error $>100 \%$

$10-15 \mathrm{~cm}$

Error $>100 \%$
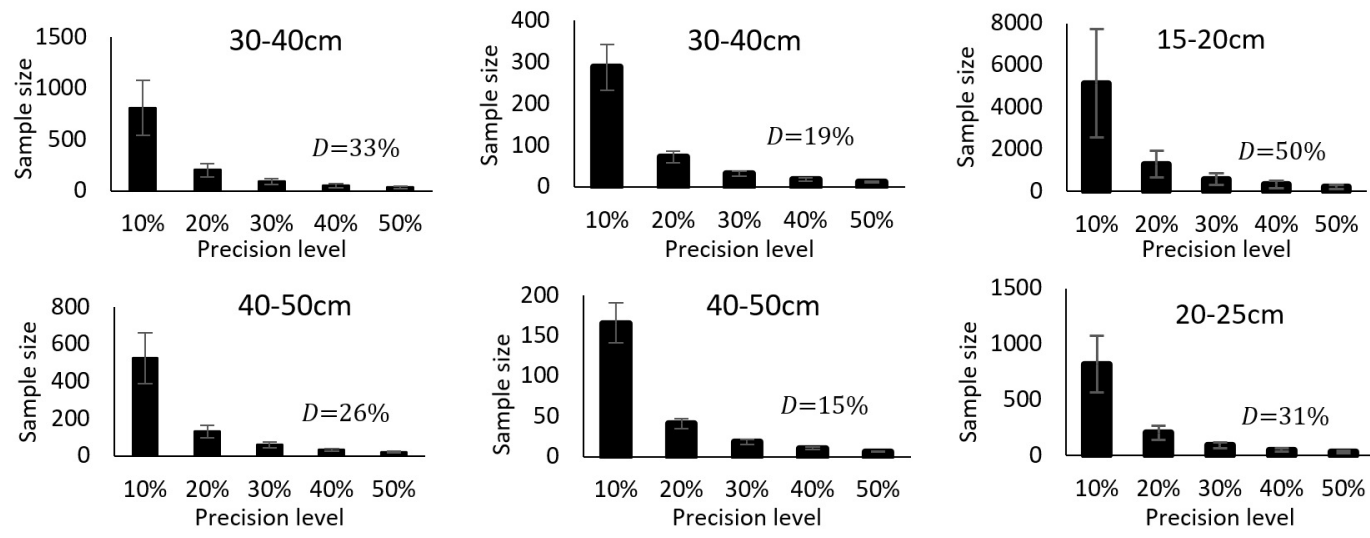

Figure 6. Minimum number of samples and error probability $(D)$ for the estimate of population density of $L y c o s a$ erythrognatha (Lucas, 1833) (Araneae: Lycosidae) in Andropogon bicornis, Saccharum angustifolium and Eustachys retusa and their respective clump diameters overwintering. Cruz Alta, Rio Grande do Sul, Brazil.

species and their clump diameter overwintering. So, these factors should be taken into account in the construction of sampling plans for L. erythrognatha for conservation biological control.

Among the limitations of our study we highlight the geographical coverage, where the work was restricted to only one place. However, the evaluated plants open much of the Brazilian territory, which raises the hypothesis of this behavior in other regions and cultivation systems, needing further research to prove or refute this hypothesis.

\section{References}

ARBAB, A., 2014. Spatial Distribution and Minimum Sample Size for Overwintering Larvae of the Rice Stem Borer Chilo suppressalis (Walker) in Paddy Fields. Neotropical Entomology, vol. 43, no. 5, pp. 415-420. http://dx.doi.org/10.1007/s13744014-0232-y. PMid:27193951.

BABA, Y.G., and TANAKA, K., 2016. Factors affecting abundance and species composition of generalist predators (Tetragnatha spiders) in agricultural ditches adjacent to rice 
paddy fields. Biological Control, vol. 103, pp. 147-153. http:// dx.doi.org/10.1016/j.biocontrol.2016.09.004.

BALDISSERA, R., GANADE, G. and FONTOURA, S.B., 2004. Web spider community response along an edge between pasture and Araucaria forest. Biological Conservation, vol. 118, no. 3, pp. 403-409.

BOLDRINI, I.I., 2009. A flora dos campos do Rio Grande do Sul. In: V.P. PILLAR, S.C. MÜLLER, Z.M.S. CASTILHOS and A.V.A. JACQUES, ed. Campos sulinos: conservação e uso sustentável da biodiversidade. 1st ed. Brasília: MMA, pp. 63-77.

BOND, J.E., GARRISON, N.L., HAMILTON, C.A., GODWIN, R.L., HEDIN, M. and AGNARSSON, I., 2014. Phylogenomics resolves a spider backbone phylogeny and rejects a prevailing paradigm for orb web evolution. Current Biology, vol. 24, no. 15, pp. 1765-1771. http://dx.doi.org/10.1016/j.cub.2014.06.034. PMid:25042592.

BORTOLOTTO, O.C., MENEZES, J.R.A.O. and HOSHINO, A.T., 2016. Abundância de inimigos naturais de pulgões do trigo em diferentes distâncias da borda da mata. Pesquisa Agropecuária Brasileira, vol. 51, no. 2. http://dx.doi.org/10.1590/S0100204X2016000200011.

BUENO, A.F., SOSA-GOMEZ, D.R., CORRÊA-FERREIRA, B.S., MOSCARDI, F. and REGIANE, C.O.F., 2012. Inimigos naturais das pragas da soja. In: C.B. HOFFMANN-CAMPO, B.S. CORRÊA-FERREIRA, F. MOSCARDI, org. SOJA: Manejo Integrado de Insetos e outros Artrópodes-Praga. 1st ed. Brasília, DF: Embrapa, pp. 493-630.

BUSSAB, W.O. and MORETTIN, P.A., 2004. Estatística básica. 5. ed. São Paulo: Saraiva, pp. 526.

CIVIDANES, F.J., 2002. Efeitos do Sistema de plantio e da consorciação soja-milho sobre artrópodes capturados no solo. Pesquisa Agropecuária Brasileira, vol. 37, no. 1, pp. 15-23. http:// dx.doi.org/10.1590/S0100-204X2002000100003.

DA SILVA, L.V., RIBEIRO, A.L. P. and LÚCIO, A.D.C., 2014. Diversidade de aranhas de solo em cultivos de milho (Zea mays). Semina: Ciências Agrárias, vol. 35, no. 4, pp. 2395-2404. https://10.5433/1679-0359.2014v35n4Suplp2395

DE SOUZA, A.L.T. 2007. Influência da estrutura do habitat na abundância e diversidade de aranhas. In: M.O. GONZAGA, A.J. SANTOS and H.F. JAPYASSÚ, orgs. Ecologia e comportamento de aranhas. Rio de Janeiro: Editora Interciência, pp. 25-43.

ENGEL, E., PASINI, M.P.B. and HÖRZ, D.C., 2018. Densidade populacional de pentatomídeos influenciada pela estrutura morfológica de diferentes plantas no município de Cruz Alta RS. Revista de Ciências Agrárias (Belém), vol. 61, pp. 1-7. http:// dx.doi.org/10.22491/rca.2018.2815.

ENGEL, E., PASINI, M.P.B., HÖRZ, D.C., BORTOLOTTO, R.P. and ZAMBERLAN, J.F., 2020. Predatory arthropods on alternative host plants in area surrounding by soybean-corn succession system. Biologia, vol. •., pp. 1336-9563. http://dx.doi. org/10.2478/s11756-019-00410-z.

HADDAD, C.R., FOORD, S.H., FOURIE, R. and DIPPENAARSCHOEMAN, A.S., 2015. Effects of fast-burning spring fire on the ground-dwelling spider assemblages (Arachnida: Araneae) in a central South Africa grassland habitat. African Zoology, vol. 50, no. 4, pp. 281-292. http://dx.doi.org/10.1080/1562702 0.2015 .1088400

HORVÁTH, R., MAGURA, T., SZINETÁR, C., EICHARDT, J., KOVÁCS, E. and TÓTHEMÉRÉSZ, B., 2015. In stable, unmanaged grasslands local factors are more important than landscape-level factors in shaping spider assemblages Agriculture, Ecosystems \& Environment, vol. 208, pp. 106-113. http://dx.doi. org/10.1016/j.agee.2015.04.033.

HORVÁTH, R., MAGURA, T., SZINETÁR, C. and TÓTHEMÉRÉSZ, B., 2009. Spiders are not less diverse in small and isolated grasslands, but less diverse in overgrazed grasslands: A field study (East Hungary, Nyérség). Agriculture, Ecosystems \& Environment, vol. 130, pp. 16-22. http://dx.doi.org/10.1016/j.agee.2008.11.011.

HOWE, G.A. and JANDER, G., 2008. Plant Immunity to insect herbivores. Annual Review of Plant Biology, vol. 59, pp. 41-66. http://dx.doi.org/10.1146/annurev.arplant.59.032607.092825. PMid: 18031220 .

KLEIN, J.T., REDAELLI, L.R. and BARCELLOS, A., 2013. Andropogon bicornis (Poales, Poaceae): A Hibernation Site for Pentatomoidea (Hemiptera: Heteroptera) in a Rice-Growing Region of Southern Brazil. Neotropical Entomology, vol. 42, no. 3, pp. 240-245. http://dx.doi.org/10.1007/s13744-013-0116-6. PMid:23949805.

KUINCHTNER, A. and BURIOL, G.A., 2016. Clima do Estado do Rio Grande do Sul segundo a classificação climática de Köppen e Thornthwaite. Disciplinarum Scientia|Ciencias Naturais e Tecnológicas, vol. 2, no. 1, pp. 171-182.

LEE, S.Y., KIM, S.T., JUNG, J.K. and LEE, J., 2014. A Comparison of Spider Communities in Bt and Non-Bt Rice Fields. Environmental Entomology, vol. 43, no. 3, pp. 819-827. http://dx.doi.org/10.1603/ EN12259. PMid:24874159.

LÚCIO, A.D., VIEIRANETO, J., CHIARADIA, L.A. and STORCK, L., 2009. Distribuição espacial e tamanho de amostra para ácarodo-bronzeado da erva mate. Revista Árvore, vol. 33, no. 1, pp. 143-150. http://dx.doi.org/10.1590/S0100-67622009000100015.

MCDONALD, B., 2007. Effects of vegetation structure on foliage dwelling spider assemblages in native and non-native Oklahoma grasslands habitats. Proc. Okla. Aead., vol. 87, pp. 85-88.

MINEO, M.F., 2009. Ecologia da comunidade de aranhas de solo de uma área de cerrado no sudeste do Brasil. Uberlândia, MG: Universidade Federal de Uberlândia, Programa de Pósgraduação em Ecologia e Conservação de Recursos Naturais. Tese de doutorado.

MORRISON, W.R., BRYANT, A.N., POLING, B., QUINN, N.F. and LESKEY, T.C., 2017. Predation of Halyomorpha halys (Hemiptera: Pentatomidae) from Web-Building Spiders Associated with Anthropogenic Dwellings. Journal of Insect Behavior, vol. 30, no. 1 , pp. 70-85.

PASINI, M.P.B., LÚCIO, A.D.C., CARGNELUTTI FILHO, A., RIBEIRO, A.L.P., ZAMBERLAN, J.F. and LOPES, S.J., 2018. Population density of Tibraca limbativentris on flood irrigated rice and alternative host plants. Pesquisa Agropecuária Brasileira, vol. 53, no. 3, pp. 265-278. http://dx.doi.org/10.1590/S0100204X2018000300001.

PATCHEY, O.L. and GASTON, K.J., 2007. Dendograms and measuring functional diversity. Oikos, vol. 116, no. 8, pp. 14221426. https://10.1111/j.2007.0030-1299.15894.x.

PODGAISKI, L.R., JONER, F., LAVOREL, S., MORETTI, M., IBANEZ, S. and MENDONÇA JUNIOR, M.S., 2013. Spider trait assembly patterns and resilience under fire-induced vegetation change in south Brazilian Grasslands. PLOS ONE, vol. 8, no. 3, pp. 1-11. https://10.1371/journal.pone.006027 
RODRIGUES, E.N.L., MENDONÇA JÚNIOR, M.S. and OTT, R., 2009. Spider diversity in a rice agroecosystem and adjacent areas in southern Brazil. Revista Colombiana de Entomologia, vol. 35 , no. 1 , pp. $78-86$.

ROMERO, G.Q., 2007. Aranhas como agentes de controle biológico em agroecossistemas. In: M.O. GONZAGA, A.J. SANTOS and H.F. JAPYASSÚ, org. Ecologia e comportamento de aranhas. Rio de Janeiro: Editora Interciência, pp. 301-315.

SOUTHWOOD, T.E.R. and HENDERSON, P.A., 2000. Ecological methods. 3. ed. New York: Wiley, 593 p.

STRATTON, G.E., UETS, G.W. and DILLERY, D.G., 1979. A comparison of the spiders of three coniferous tree species. The Journal of Arachnology, vol. 6, pp. 219-226.
SUJII, E.R., VENZON, M., PIRES, C.S.S. and TOGNI, P.H.B., 2010. Práticas culturais no manejo de pragas na agricultura orgânica. In: M. VENZON, T.J. PAULA JUNIOR and A. PALLINI, org. Controle alternativo de pragas e doenças na agricultura orgânica. Viçosa: EPAMIG, vol. 1, pp. 43-168.

TAYLOR, L.R., 1961. Aggregation, variance and the mean. Nature, vol. 189, pp. 732-735. http://dx.doi.org/10.1038/189732a0.

VINATIER, F., TIXIER, P., DUYCK, P.F. and LESCOURRET, F., 2011. Factors and mechanisms explaining spatial heterogeneity: a review of methods for insect populations. Methods Ecology Evolution, vol. 2, no. 1, pp. 11-22. https://doi.org/10.1111/j.2041-210X.2010.00059.x

World Spider Catalog, 2020. [viewed 09 September 2020]. World Spider Catalog Ver. 21.5. Natural History Museum Bern. Available from: https://wsc.nmbe.ch/. 